\title{
Basic experimental unit and plot sizes for fresh matter of sunn hemp
}

\section{Giovani Facco ${ }^{1} \odot$ Alberto Cargnelutti Filho $^{2} \odot$ André Lavezo $^{1} \odot$

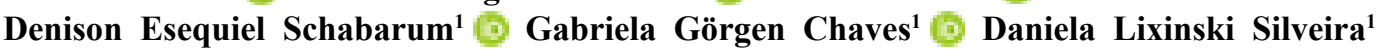

\footnotetext{
${ }^{1}$ Programa de Pós-graduação em Agronomia, Universidade Federal de Santa Maria (UFSM), Santa Maria, RS, Brasil.

${ }^{2}$ Departamento de Fitotecnia, Universidade Federal de Santa Maria (UFSM), 97105-900, Santa Maria, RS, Brasil. E-mail: alberto.cargnelutti.filho@gmail.com. ${ }^{*}$ Corresponding author.
}

\begin{abstract}
This study aimed to verify the influence of the basic experimental unit (BEU) size in the estimation of the optimum plot size to evaluate the fresh matter of sunn hemp (Crotalaria juncea L.) using the modified maximum curvature method. The fresh matter of sunn hemp was evaluated in uniformity trials in two sowing season in flowering. In each sowing season, 4,608 BEUs of $0.5 \times 0.5 \mathrm{~m}\left(0.25 \mathrm{~m}^{2}\right)$ were evaluated and 36 BEU plans were formed with sizes from 0.25 to $16 \mathrm{~m}^{2}$. In each evaluation period for each BEU plan, using fresh matter data, optimum plot size was estimated through the modified maximum curvature method. Estimation of the optimum plot size depends on the BEU size. Assessing fresh matter in BEUs that are as small as possible is recommended in order to use it to estimate the optimum plot size.

Key words: Crotalaria juncea L., modified maximum curvature, uniformity trials, experimental planing.
\end{abstract}

Tamanhos de unidade experimental básica e de parcela para massa de matéria verde de crotalária juncea

RESUMO: O objetivo deste trabalho foi verificar a influência do tamanho da unidade experimental básica (UEB) na estimativa do tamanho ótimo de parcela, para a avaliação da massa de matéria verde de crotalária juncea (Crotalaria juncea L.), pelo método da máxima curvatura modificado. Avaliou-se a massa de matéria verde de crotalária juncea, no florescimento da cultura, em ensaios de uniformidade conduzidos em duas épocas de semeadura. Em cada época foram avaliadas 4.608 UEB de 0,5×0,5m (0,25 $\left.{ }^{2}\right)$ e formaram-se 36 planos de UEB com tamanhos entre 0,25 e $16 \mathrm{~m}^{2}$. Em cada época, para cada plano de UEB, com os dados de massa de matéria verde, estimou-se o tamanho ótimo de parcela, pelo método da máxima curvatura modificado. A estimativa do tamanho ótimo de parcela depende do tamanho da unidade experimental básica. É indicado avaliar a massa de matéria verde em UEB de menor tamanho possível, para serem usadas na estimação do tamanho ótimo de parcela.

Palavras-chave: Crotalaria juncea L., máxima curvatura modificado, ensaios de uniformidade, planejamento experimental.

\section{INTRODUCTION}

Sunn hemp (Crotalariajuncea L.), belonging to the Fabaceae family, is an annual shrub with erect and determinate growth. The species is used as a cover crop or green manure (LEAL et al., 2012). In the evaluation of the agronomic aspects of legumes for green manure, TEODORO et al. (2011) concluded that sunn hemp is a promising species due to its high capacity for biomass production and nitrogen fixation. Moreover, COLLIER et al. (2006) verified that the residues of sunn hemp contributed to higher grain yield in maize.

Adequate experimental planning is necessary due to the relevance of this crop and so that research can produce results that translate well into real-world scenarios.
An important aspect of planning is to use an optimum plot size. This size can be defined from data collected in uniformity trials, i.e., trials without the application of treatments (RAMALHO et al., 2012; STORCK et al., 2016). To determine the optimum plot size based on the traits of an agricultural crop, uniformity trials are divided into basic experimental units (BEUs) of the smallest possible size, from which the data are collected.

The size of the BEU is determined by the researcher and might vary according to the subject of study, not having an ideal size for each crop. However, the BEU is usually adopted as small as possible. The influence of BEU size on the estimation of optimum plot size is poorly examined in soil cover crops such as sunn hemp. OLIVEIRA et al. (2005) verified the effect 
of BEU size on the optimum plot size in potato crop, estimated by the modified maximum curvature method (MEIER \& LESSMAN, 1971). They concluded that the BEU size influences the estimated optimum plot size. However, crops used for another purpose, such as for soil cover in the case of sunn hemp, might respond differently to environmental stimuli. Therefore, the influence of BEU size on the estimation of optimum plot size might differ between crops.

Studies on the influence of BEU size on the estimation of optimum plot size, obtained by the method of maximum curvature of coefficient of variation model (PARANAÍBA et al., 2009), were developed to evaluate the fresh matter of white lupine (CARGNELUTTI FILHO et al., 2016b), forage turnip (CARGNELUTTI FILHO et al., 2016a), and sunn hemp (FACCO et al., 2017). These studies demonstrated that, for this method and these crops, the estimation of the optimum plot size depends on the BEU size. Additionally, it was indicated that evaluating fresh matter in the smallest possible size should be used to estimate optimum plot size.

In the modified maximum curvature method (MEIER \& LESSMAN, 1971), adjacent BEU groupings should be formed. In the method of maximum curvature of coefficient of variation model (PARANAÍBA et al., 2009), it is unnecessary to group BEUs, though this fact is considered an advantage of this method. Such variations in the grouping of BEUs and all other calculations of each method make them different, as do the possible differences in the extent of which BEU size influences the estimation of the optimum plot size. It is important to have a method in which the plot size estimation has no influence on BEU size. Thus, it is relevant to investigate the influence of BEU size on the estimation of the optimum plot size for different methods and agricultural crops.

The soil heterogeneity index and the experimental material are factors that can alter the optimum plot size (STEEL et al., 1997). The size and heterogeneity of the BEU can alter the variance and the soil heterogeneity index, changing the optimum plot size. Among the statistical methods for estimating the optimum plot size, some are derived from the empirical relationship described by SMITH (1938). In this relationship, the soil heterogeneity index (b) is estimated, which describes the correlation between the adjacent plots. Conversely, $b$ accounts for the real variation in the soil as well as the variations that occurred in the collection of the experimental data, in addition to natural variations in the production of the plants regarding climate and management (SMITH, 1938).

Soil heterogeneity index values close to 1 indicate high soil heterogeneity, that is, low correlation between the adjacent plots (GOMEZ \& GOMEZ, 1984), inflating the optimum plot size. Plot size studies following the protocol of MEIER \& LESSMAN (1971) have been carried out to evaluate the number of ears, ear weight, and grain yield in wheat (LORENTZ et al., 2007); grain yield evaluation of sorghum (BRUM et al., 2008); comparison of estimation methods of optimum plot size in maize (CARGNELUTTI FILHO et al., 2011); and evaluation of grain yield in sunflower (SOUZA et al., 2015), which reveals the importance of this method for its wide use in research.

The literature does not discuss whether the size of the BEU influences the estimation of the optimum plot size, obtained through the method of MEIER \& LESSMAN (1971), for sunn hemp. Thus, this study aimed to verify the influence of the BEU size in the estimation of the optimum plot size to evaluate the fresh matter of sunn hemp, using the modified maximum curvature method.

\section{MATERIALS AND METHODS}

Two uniformity trials (blank experiments) were conducted using sunn hemp in an experimental area of $50 \times 52 \mathrm{~m}\left(2,600 \mathrm{~m}^{2}\right)$ in the Department of Plant Science at the Universidade Federal de Santa Maria, Rio Grande do Sul in Southern Brazil (29 $42^{\prime} \mathrm{S}$; 53 $3^{\circ} 49^{\prime} \mathrm{W}$; and elevation $=95 \mathrm{~m}$ ). According to the Köppen Climate Classification, the climate of the region is Cfa subtropical humid, with hot summers and no defined dry season (HELDWEIN et al., 2009). The soil is classified as 'Argissolo Vermelho distrófico arênico’ (SANTOS et al., 2013).

Two uniformity trials were conducted in the agricultural year $2014 / 2015$. In the first season (first trial), sowing was performed on October 22, 2014 in an area of $50 \times 26 \mathrm{~m}\left(1,300 \mathrm{~m}^{2}\right)$. In the second season (second trial), sowing was carried out on December 3,2014 , in area of $50 \times 26 \mathrm{~m}\left(1,300 \mathrm{~m}^{2}\right)$. In both seasons, seeds were sown in rows, spaced $0.50 \mathrm{~m}$ apart. After the emergency, plants were thinned, and the density was adjusted to 20 plants per row meter. Base fertilization was $15 \mathrm{~kg} \mathrm{ha}^{-1}$ of $\mathrm{N}, 60 \mathrm{~kg} \mathrm{ha}^{-1}$ of $\mathrm{P}_{2} \mathrm{O}_{5}$, and $60 \mathrm{~kg} \mathrm{ha}^{-1}$ of $\mathrm{K}_{2} \mathrm{O}$. Culture treatments (fertilization, weed control, pests, and diseases) in the uniformity trial were the same throughout the experimental area, as suggested by STORCK et al. (2016). Trials were conducted on sowing season to take into consideration the environmental oscillations that can influence their characteristics. Additionally, for each sowing season, the dimensions of these trials were planned to cover greater variability. These aspects are important to ensure the representativeness of the database and, consequently, reliability of the inferences of this study. 
In each sowing season, at the center of the uniformity trial, an area of $48 \times 24 \mathrm{~m}\left(1,152 \mathrm{~m}^{2}\right)$ was demarcated. The area of each trial was divided into $4,608 \mathrm{BEU}$ of $0.5 \times 0.5 \mathrm{~m}\left(0.25 \mathrm{~m}^{2}\right)$, forming a matrix of 96 lines and 48 columns. In each BEU during flowering in the first sowing season - 110 days after sowing (DAS) - and second sowing season (97 DAS), plants were cut close to the soil and fresh matter weight was determined in grams.

In each sowing season, with the fresh matter data of 4,608 BEUs, 36 BEUs sizes (plans) of dimensions $\mathrm{X}=\mathrm{X}_{\mathrm{L}} \times \mathrm{X}_{\mathrm{C}}(\mathrm{X}=0.25,0.50,0.75,1,1.5,2,2.25,3$, $4,4.5,6,8,9,12$, and $16 \mathrm{~m}^{2}$ ) were planned (Table 1). Abbreviations $\mathrm{X}_{\mathrm{L}}, \mathrm{X}_{\mathrm{C}}$, and $\mathrm{X}$, represent the number of BEUs adjacent to the line, number of BEUs adjacent to the column, and BEU size, in the number of BEU or $\mathrm{m}^{2}$, respectively. Thus, the 36 plans of BEU were formed between $0.5 \times 0.5 \mathrm{~m}\left(1 \mathrm{BEU}=0.25 \mathrm{~m}^{2}\right)$ and $4 \times 4 \mathrm{~m}$ $\left(64 \mathrm{BEU}=16 \mathrm{~m}^{2}\right)$. For composition of plans, values of fresh matter for $\mathrm{X}_{\mathrm{L}} \mathrm{BEU}$ adjacent to the line and for $\mathrm{X}_{\mathrm{C}}$ BEU adjacent to the column were added. For each plan, $\mathrm{n}$ indicates the number of plots with $\mathrm{X}$ BEU of size $(n=4,608 / X)$ were determined. Sub plans were made for each plan (Table 1) - necessary for the application of the modified maximum curvature method (MEIER \& LESSMAN, 1971).

In each of the 36 plans, the modified maximum curvature method (MEIER \& LESSMAN, 1971) was applied, and the coefficient of variation was estimated for $\mathrm{X}$ equal to a BEU (A), B, and the coefficient of determination $\left(\mathrm{R}^{2}\right)$ of the function $\mathrm{CV}(\mathrm{x})=\mathrm{A} / \mathrm{X}^{\mathrm{B}}$. These parameters were estimated through the logarithmic transformation of the function $\mathrm{CV}_{\mathrm{X})}=\mathrm{A} / \mathrm{X}^{\mathrm{B}}$ and the weighting by degrees of freedom (STEEL et al., 1997). Although, not used in the modified maximum curvature method (MEIER \& LESSMAN, 1971), the estimates of the variance of the plot of a BEU (V1), soil heterogeneity index (b), and determination coefficient $\left(\mathrm{R}^{2}\right)$ were obtained from the equation $\mathrm{VU}(\mathrm{x})=\mathrm{V} 1 / \mathrm{X}^{\mathrm{b}}$ (SMITH, 1938). Parameters V1 and b were estimated through the logarithmic transformation of function and weighting by degrees of freedom (STEEL et al., 1997). Plot means of a BEU (m) and the coefficient of variation corresponding to the optimum plot size were determined. The point corresponding to the optimum plot size (Xo, in BEU), by modified maximum curvature method (MEIER \& LESSMAN, 1971), was determined by the expression $\mathrm{Xo}_{0}=\left[\mathrm{A}^{2} \mathrm{~B}^{2}(2 \mathrm{~B}+1) /(\mathrm{B}+2)\right]^{1 /(\mathrm{B}+2)]}$. The optimum plot size $\left(\mathrm{Xo}\right.$, in $\left.\mathrm{m}^{2}\right)$ was as the by product of $\mathrm{Xo}$ (in BEU), by the BEU area (in $\mathrm{m}^{2}$ ).

\section{RESULTS AND DISCUSSION}

Based on the fresh matter data of sunn hemp between the sowing seasons, the variability of the soil heterogeneity index (b) estimates was observed, as were the parameters $\mathrm{A}$ and $\mathrm{B}$ of the $\mathrm{CV}(\mathrm{x})=\mathrm{A} / \mathrm{X}^{\mathrm{B}}$ function, the plot mean of $1 \mathrm{BEU}(\mathrm{m})$, and the optimum plot size (Xo) (Tables 2 and 3 ). Variability between sowing seasons can likely be attributed to variations in environmental conditions, as the trials were implemented during different sowing seasons. Variations between the means within the same sowing season are due to the variable size of the trial in $X_{L}$ (number of BEUs adjacent to the line) and $X_{C}$ (number of BEUs adjacent to the column).

The coefficient of variation for plot size $\left(\mathrm{CV}_{\mathrm{x}_{0}}\right)$ decreased as the BEU increased in the experimental plans. This pattern of behavior was expected because the increase of BEU in the experimental plans directly influences the standard deviation, which in turn is used in the estimation of the coefficient of variation (OLIVEIRA et al., 2011). Similar behavior can be evidenced for both parameters B and the soil heterogeneity index (b).

In season 1 , estimates of the soil heterogeneity index (b) ranged from 0.36-0.84, whereas in season 2 the values were lower, ranging between $0.27-0.78$. For season $1,19.44 \%$ of the values for $b$ were higher than 0.7 , while $13.88 \%$ of the values for b were higher than 0.7 for season 2, indicating a low correlation between adjacent plots. Between the two evaluation seasons, the minimum value for $\mathrm{b}$ was 0.27 . According to HALLAUER (1964), estimates of $b$ vary less between environments than they do between years. Additionally, for values of b close to zero, the interpretation of LIN \& BINNS (1986) indicated the use of higher repetition and smaller plot size to maximize experimental precision.

In the method outlined by MEIER \& LESSMAN (1971), the optimum plot size is determined based on the estimates of parameters A and B. Parameter A corresponds to the coefficient of variation per plot consisting of a BEU, whereas parameter $\mathrm{B}$ is twice the value of the soil heterogeneity index (i.e., $\mathrm{B}=2 \mathrm{~b}$ ). In general, as BEU size increased, estimates of $\mathrm{A}$ and $\mathrm{B}$ decreased; consequently, there was a decrease in the optimum plot size in BEU (Xo, BEU) (Figure 1). In potato, it was observed that larger trial widths were related to lower estimates of $\mathrm{A}, \mathrm{B}, \mathrm{b}$, and $\mathrm{Xo}$, while longer trial areas led to greater experimental precision (STORCK et al., 2006).

Estimates of parameter A influenced the plot size estimation for season 1 in experimental plans with a BEU size of 0.25 and $16 \mathrm{~m}^{2}$. Estimates of A ranged from 51.40 to 10.70 , and plot sizes estimated were 7.91 and 1.70 BEU, respectively (Table 2). For season 2, in experimental plans with BEU size of 0.25 and $16 \mathrm{~m}^{2}$, 
Table 1 - Format of the 36 plans (basic experimental unit size, in $\mathrm{m}^{2}$ ) planned from 4,608 basic experimental units of $0.5 \times 0.5 \mathrm{~m}\left(0.25 \mathrm{~m}^{2}\right)$ of a matrix of 96 lines and 48 columns. Format the 36 sub plans and the sub plans used for each plan, for the determination of plot size by method of MEIER \& LESSMAN (1971).

\begin{tabular}{|c|c|c|c|c|c|c|c|}
\hline \multicolumn{4}{|c|}{-------------Plans------------ } & \multicolumn{3}{|c|}{---Sub plans--- } & \multirow{2}{*}{ 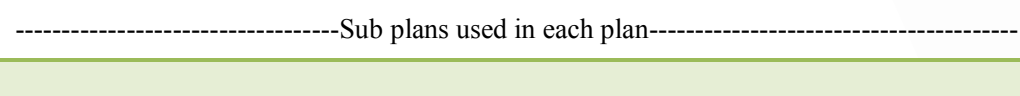 } \\
\hline $\mathrm{N}^{\mathrm{o}}$ & $\mathrm{X}_{\mathrm{L}}$ & $\mathrm{X}_{\mathrm{C}}$ & $\mathrm{m}^{2}$ & $\mathrm{~N}^{\mathrm{o}}$ & $\mathrm{X}_{\mathrm{L}}$ & $\mathrm{X}_{\mathrm{C}}$ & \\
\hline 1 & 1 & 1 & 0.25 & 1 & 1 & 1 & $\begin{array}{c}1,2,3,4,5,6,7,8,9,10,11,12,13,14,15,16,17,18,19,20,21,22,23,24,25,26,27, \\
28,29,30,31,32,33,34,35 \text {, and } 36\end{array}$ \\
\hline 2 & 1 & 2 & 0.50 & 2 & 1 & 2 & $\begin{array}{c}1,2,3,4,5,6,7,8,9,10,11,12,13,14,15,16,17,18,19,20,21,22,23,24,25,26,27 \\
28,29,30,31,32,33,34,35, \text { and } 36\end{array}$ \\
\hline 3 & 1 & 3 & 0.75 & 3 & 1 & 3 & $1,2,4,6,7,8,10,12,13,14,16,18,19,20,22,24,25,26,28,30,31,32,34$, and 36 \\
\hline 4 & 1 & 4 & 1.00 & 4 & 1 & 4 & $\begin{array}{c}1,2,3,4,5,7,8,9,10,11,13,14,15,16,17,19,20,21,22,23,25,26,27,28,29,31,32, \\
33,34, \text { and } 35\end{array}$ \\
\hline 5 & 1 & 6 & 1.50 & 5 & 1 & 6 & $1,2,4,6,7,8,10,12,13,14,16,18,19,20,22,24,25,26,28,30,31,32,34$, and 36 \\
\hline 6 & 1 & 8 & 2.00 & 6 & 1 & 8 & $1,2,3,5,7,8,9,11,13,14,15,17,19,20,21,23,25,26,27,29,31,32,33$, and 35 \\
\hline 7 & 2 & 1 & 0.50 & 7 & 2 & 1 & $\begin{array}{c}1,2,3,4,5,6,7,8,9,10,11,12,13,14,15,16,17,18,19,20,21,22,23,24,25,26,27, \\
28,29,30,31,32,33,34,35, \text { and } 36\end{array}$ \\
\hline 8 & 2 & 2 & 1.00 & 8 & 2 & 2 & $\begin{array}{c}1,2,3,4,5,6,7,8,9,10,11,12,13,14,15,16,17,18,19,20,21,22,23,24,25,26,27, \\
28,29,30,31,32,33,34,35, \text { and } 36\end{array}$ \\
\hline 9 & 2 & 3 & 1.50 & 9 & 2 & 3 & $1,2,4,6,7,8,10,12,13,14,16,18,19,20,22,24,25,26,28,30,31,32,34$, and 36 \\
\hline 10 & 2 & 4 & 2.00 & 10 & 2 & 4 & $\begin{array}{c}1,2,3,4,5,7,8,9,10,11,13,14,15,16,17,19,20,21,22,23,25,26,27,28,29,31,32, \\
33,34, \text { and } 35\end{array}$ \\
\hline 11 & 2 & 6 & 3.00 & 11 & 2 & 6 & $1,2,4,6,7,8,10,12,13,14,16,18,19,20,22,24,25,26,28,30,31,32,34$, and 36 \\
\hline 12 & 2 & 8 & 4.00 & 12 & 2 & 8 & $1,2,3,5,7,8,9,11,13,14,15,17,19,20,21,23,25,26,27,29,31,32,33$, and 35 \\
\hline 13 & 3 & 1 & 0.75 & 13 & 3 & 1 & $1,2,3,4,5,6,7,8,9,10,11,12,19,20,21,22,23,24,31,32,33,34,35$, and 36 \\
\hline 14 & 3 & 2 & 1.50 & 14 & 3 & 2 & $1,2,3,4,5,6,7,8,9,10,11,12,19,20,21,22,23,24,31,32,33,34,35$, and 36 \\
\hline 15 & 3 & 3 & 2.25 & 15 & 3 & 3 & $1,2,4,6,7,8,10,12,19,20,22,24,31,32,34$, and 36 \\
\hline 16 & 3 & 4 & 3.00 & 16 & 3 & 4 & $1,2,3,4,5,7,8,9,10,11,19,20,21,22,23,31,32,33,34$, and 35 \\
\hline 17 & 3 & 6 & 4.50 & 17 & 3 & 6 & $1,2,4,6,7,8,10,12,19,20,22,24,31,32,34$, and 36 \\
\hline 18 & 3 & 8 & 6.00 & 18 & 3 & 8 & $1,2,3,5,7,8,9,11,19,20,21,23,31,32,33$, and 35 \\
\hline 19 & 4 & 1 & 1.00 & 19 & 4 & 1 & $\begin{array}{c}1,2,3,4,5,6,7,8,9,10,11,12,13,14,15,16,17,18,19,20,21,22,23,24,25,26,27, \\
28,29,30,31,32,33,34,35, \text { and } 36\end{array}$ \\
\hline 20 & 4 & 2 & 2.00 & 20 & 4 & 2 & $\begin{array}{c}1,2,3,4,5,6,7,8,9,10,11,12,13,14,15,16,17,18,19,20,21,22,23,24,25,26,27, \\
28,29,30,31,32,33,34,35, \text { and } 36\end{array}$ \\
\hline 21 & 4 & 3 & 3.00 & 21 & 4 & 3 & $1,2,4,6,7,8,10,12,13,14,16,18,19,20,22,24,25,26,28,30,31,32,34$, and 36 \\
\hline 22 & 4 & 4 & 4.00 & 22 & 4 & 4 & $\begin{array}{c}1,2,3,4,5,7,8,9,10,11,13,14,15,16,17,19,20,21,22,23,25,26,27,28,29,31,32, \\
33,34, \text { and } 35\end{array}$ \\
\hline 23 & 4 & 6 & 6.00 & 23 & 4 & 6 & $1,2,4,6,7,8,10,12,13,14,16,18,19,20,22,24,25,26,28,30,31,32,34$, and 36 \\
\hline 24 & 4 & 8 & 8.00 & 24 & 4 & 8 & $1,2,3,5,7,8,9,11,13,14,15,17,19,20,21,23,25,26,27,29,31,32,33$, and 35 \\
\hline 25 & 6 & 1 & 1.50 & 25 & 6 & 1 & $1,2,3,4,5,6,7,8,9,10,11,12,19,20,21,22,23,24,31,32,33,34,35$, and 36 \\
\hline 26 & 6 & 2 & 3.00 & 26 & 6 & 2 & $1,2,3,4,5,6,7,8,9,10,11,12,19,20,21,22,23,24,31,32,33,34,35$, and 36 \\
\hline 27 & 6 & 3 & 4.50 & 27 & 6 & 3 & $1,2,4,6,7,8,10,12,19,20,22,24,31,32,34$, and 36 \\
\hline 28 & 6 & 4 & 6.00 & 28 & 6 & 4 & $1,2,3,4,5,7,8,9,10,11,19,20,21,22,23,31,32,33,34$, and 35 \\
\hline 29 & 6 & 6 & 9.00 & 29 & 6 & 6 & $1,2,4,6,7,8,10,12,19,20,22,24,31,32,34$, and 36 \\
\hline 30 & 6 & 8 & 12.00 & 30 & 6 & 8 & $1,2,3,5,7,8,9,11,19,20,21,23,31,32,33$, and 35 \\
\hline 31 & 8 & 1 & 2.00 & 31 & 8 & 1 & $\begin{array}{c}1,2,3,4,5,6,7,8,9,10,11,12,13,14,15,16,17,18,19,20,21,22,23,24,25,26,27, \\
28,29, \text { and } 30\end{array}$ \\
\hline 32 & 8 & 2 & 4.00 & 32 & 8 & 2 & $\begin{array}{c}1,2,3,4,5,6,7,8,9,10,11,12,13,14,15,16,17,18,19,20,21,22,23,24,25,26,27 \text {, } \\
28,29, \text { and } 30\end{array}$ \\
\hline 33 & 8 & 3 & 6.00 & 33 & 8 & 3 & $1,2,4,6,7,8,10,12,13,14,16,18,19,20,22,24,25,26,28$, and 30 \\
\hline 34 & 8 & 4 & 8.00 & 34 & 8 & 4 & $1,2,3,4,5,7,8,9,10,11,13,14,15,16,17,19,20,21,22,23,25,26,27,28$, and 29 \\
\hline 35 & 8 & 6 & 12.00 & 35 & 8 & 6 & $1,2,4,6,7,8,10,12,13,14,16,18,19,20,22,24,25,26,28$, and 30 \\
\hline 36 & 8 & 8 & 16.00 & 36 & 8 & 8 & $1,2,3,5,7,8,9,11,13,14,15,17,19,20,21,23,25,26,27$, and 29 \\
\hline
\end{tabular}

$\mathrm{X}_{\mathrm{L}}$ - number of BEUs adjacent to the line; and $\mathrm{X}_{\mathrm{C}}$ - number of BEUs adjacent to the column. 
Table 2 - Basic experimental unit (BEU) plans with size $\mathrm{X}=\mathrm{X}_{\mathrm{L}} \times \mathrm{X}_{\mathrm{C}}$, in BEU and $\mathrm{m}^{2}$, and respective estimates of the parameters of the functions $\mathrm{CV}(\mathrm{x})=\mathrm{A} / \mathrm{X}^{\mathrm{B}}$ and $\mathrm{VU}(\mathrm{x})=\mathrm{V} 1 / \mathrm{X}^{\mathrm{b}}$, coefficient of determination $\left(\mathrm{R}^{2}\right)$, mean of fresh matter in the plots of a BEU $(\mathrm{m})$, coefficient of variation of the optimum plot size $\left(\mathrm{CV}_{\mathrm{Xo}}\right.$, in \%), optimum plot size obtained by modified maximum curvature method (Xo, in BEU; and Xo in $\left.\mathrm{m}^{2}\right)$ for the fresh matter of sunn hemp (Crotalaria juncea L.), evaluated at 110 days after sowing (first sowing season), in uniformity trial with $4,608 \mathrm{BEU}$ of $0.5 \times 0.5 \mathrm{~m}\left(0.25 \mathrm{~m}^{2}\right)$.

\begin{tabular}{|c|c|c|c|c|c|c|c|c|c|c|c|c|c|c|c|}
\hline Plan & $\mathrm{X}_{\mathrm{L}}$ & $\mathrm{X}_{\mathrm{C}}$ & $\begin{array}{c}\mathrm{X} \\
(\mathrm{BEU})\end{array}$ & $\begin{array}{c}X \\
\left(\mathrm{~m}^{2}\right)\end{array}$ & $\mathrm{n}$ & A & $\mathrm{B}$ & $\mathrm{R}^{2}$ & V1 & $\mathrm{b}$ & $\mathrm{R}^{2}$ & $\mathrm{~m}$ & $\mathrm{CV}_{\mathrm{Xo}}$ & $\begin{array}{c}\text { Xo } \\
\text { (BEU) }\end{array}$ & $\begin{array}{c}\text { Xo } \\
\left(\mathrm{m}^{2}\right)\end{array}$ \\
\hline 1 & 1 & 1 & 1 & 0.25 & 4608 & 51.40 & 0.42 & 0.99 & $307,164.17$ & 0.84 & 0.99 & $1,078.28$ & 21.46 & 7.91 & 1.98 \\
\hline 2 & 1 & 2 & 2 & 0.5 & 2304 & 37.98 & 0.38 & 0.96 & $670,893.64$ & 0.77 & 0.96 & $2,156.55$ & 18.83 & 6.22 & 3.11 \\
\hline 3 & 1 & 3 & 3 & 0.75 & 1536 & 32.47 & 0.38 & 0.94 & $1,103,572.94$ & 0.75 & 0.94 & $3,234.83$ & 17.09 & 5.52 & 4.14 \\
\hline 4 & 1 & 4 & 4 & 1 & 1152 & 29.67 & 0.36 & 0.93 & $1,637,994.44$ & 0.73 & 0.93 & $4,313.11$ & 16.39 & 5.10 & 5.10 \\
\hline 5 & 1 & 6 & 6 & 1.5 & 768 & 26.13 & 0.37 & 0.91 & $2,858,065.66$ & 0.73 & 0.91 & $6,469.66$ & 14.89 & 4.66 & 6.99 \\
\hline 6 & 1 & 8 & 8 & 2 & 576 & 24.43 & 0.36 & 0.91 & $4,440,524.47$ & 0.73 & 0.91 & $8,626.22$ & 14.19 & 4.43 & 8.86 \\
\hline 7 & 2 & 1 & 2 & 0.5 & 2304 & 36.27 & 0.39 & 0.98 & $611,863.77$ & 0.77 & 0.98 & $2,156.55$ & 18.17 & 6.03 & 3.01 \\
\hline 8 & 2 & 2 & 4 & 1 & 1152 & 26.88 & 0.34 & 0.94 & $1,344,445.95$ & 0.68 & 0.94 & $4,313.11$ & 15.98 & 4.61 & 4.61 \\
\hline 9 & 2 & 3 & 6 & 1.5 & 768 & 23.42 & 0.34 & 0.93 & $2,295,049.12$ & 0.68 & 0.93 & $6,469.66$ & 14.48 & 4.14 & 6.22 \\
\hline 10 & 2 & 4 & 8 & 2 & 576 & 21.12 & 0.32 & 0.89 & $3,319,810.07$ & 0.63 & 0.89 & $8,626.22$ & 13.98 & 3.70 & 7.40 \\
\hline 11 & 2 & 6 & 12 & 3 & 384 & 18.98 & 0.33 & 0.89 & $6,032,868.25$ & 0.67 & 0.89 & $12,939.33$ & 12.47 & 3.52 & 10.56 \\
\hline 12 & 2 & 8 & 16 & 4 & 288 & 18.05 & 0.34 & 0.87 & $9,699,229.86$ & 0.67 & 0.87 & $17,252.43$ & 11.95 & 3.40 & 13.62 \\
\hline 13 & 3 & 1 & 3 & 0.75 & 1536 & 29.35 & 0.35 & 0.98 & $901,419.70$ & 0.70 & 0.98 & $3,234.83$ & 16.78 & 4.97 & 3.73 \\
\hline 14 & 3 & 2 & 6 & 1.5 & 768 & 21.66 & 0.29 & 0.97 & $1,964,566.66$ & 0.58 & 0.97 & $6,469.66$ & 14.92 & 3.60 & 5.41 \\
\hline 15 & 3 & 3 & 9 & 2.25 & 512 & 18.81 & 0.28 & 0.98 & $3,331,196.20$ & 0.56 & 0.98 & $9,704.49$ & 13.63 & 3.16 & 7.10 \\
\hline 16 & 3 & 4 & 12 & 3 & 384 & 17.18 & 0.26 & 0.95 & $4,938,793.23$ & 0.52 & 0.95 & $12,939.33$ & 13.15 & 2.80 & 8.40 \\
\hline 17 & 3 & 6 & 18 & 4.5 & 256 & 15.41 & 0.28 & 0.96 & $8,940,137.27$ & 0.55 & 0.96 & $19,408.99$ & 11.73 & 2.68 & 12.05 \\
\hline 18 & 3 & 8 & 24 & 6 & 192 & 14.56 & 0.27 & 0.92 & $14,198,743.66$ & 0.54 & 0.92 & $25,878.65$ & 11.35 & 2.52 & 15.12 \\
\hline 19 & 4 & 1 & 4 & 1 & 1152 & 25.30 & 0.32 & 0.97 & $1,190,482.16$ & 0.64 & 0.97 & $4,313.11$ & 15.91 & 4.27 & 4.27 \\
\hline 20 & 4 & 2 & 8 & 2 & 576 & 18.55 & 0.26 & 0.95 & $2,560,076.87$ & 0.52 & 0.95 & $8,626.22$ & 13.97 & 2.98 & 5.95 \\
\hline 21 & 4 & 3 & 12 & 3 & 384 & 16.29 & 0.25 & 0.96 & $4,440,234.53$ & 0.50 & 0.96 & $12,939.33$ & 12.80 & 2.62 & 7.86 \\
\hline 22 & 4 & 4 & 16 & 4 & 288 & 14.33 & 0.21 & 0.95 & $6,110,593.87$ & 0.42 & 0.95 & $17,252.43$ & 12.26 & 2.09 & 8.34 \\
\hline 23 & 4 & 6 & 24 & 6 & 192 & 12.99 & 0.24 & 0.91 & $11,305,122.13$ & 0.48 & 0.91 & $25,878.65$ & 10.86 & 2.11 & 12.68 \\
\hline 24 & 4 & 8 & 32 & 8 & 144 & 12.26 & 0.23 & 0.82 & $17,907,086.47$ & 0.46 & 0.82 & $34,504.87$ & 10.52 & 1.95 & 15.61 \\
\hline 25 & 6 & 1 & 6 & 1.5 & 768 & 21.74 & 0.30 & 0.97 & $1,978,072.51$ & 0.59 & 0.97 & $6,469.66$ & 14.79 & 3.66 & 5.49 \\
\hline 26 & 6 & 2 & 12 & 3 & 384 & 16.44 & 0.24 & 0.96 & $4,527,196.18$ & 0.48 & 0.96 & $12,939.33$ & 13.10 & 2.57 & 7.70 \\
\hline 27 & 6 & 3 & 18 & 4.5 & 256 & 14.54 & 0.23 & 0.97 & $7,959,478.23$ & 0.47 & 0.97 & $19,408.99$ & 12.00 & 2.27 & 10.23 \\
\hline 28 & 6 & 4 & 24 & 6 & 192 & 13.18 & 0.20 & 0.95 & $11,639,559.67$ & 0.41 & 0.95 & $25,878.65$ & 11.57 & 1.89 & 11.35 \\
\hline 29 & 6 & 6 & 36 & 9 & 128 & 11.99 & 0.24 & 0.92 & $21,650,301.07$ & 0.47 & 0.92 & $38,817.98$ & 10.22 & 1.96 & 17.67 \\
\hline 30 & 6 & 8 & 48 & 12 & 96 & 11.38 & 0.23 & 0.81 & $34,716,602.70$ & 0.45 & 0.81 & $51,757.30$ & 9.96 & 1.81 & 21.73 \\
\hline 31 & 8 & 1 & 8 & 2 & 576 & 19.51 & 0.28 & 0.97 & $2,832,197.11$ & 0.56 & 0.97 & $8,626.22$ & 14.07 & 3.24 & 6.47 \\
\hline 32 & 8 & 2 & 16 & 4 & 288 & 14.81 & 0.22 & 0.95 & $6,530,409.78$ & 0.44 & 0.95 & $17,252.43$ & 12.45 & 2.20 & 8.82 \\
\hline 33 & 8 & 3 & 24 & 6 & 192 & 13.36 & 0.22 & 0.95 & $11,954,897.80$ & 0.44 & 0.95 & $25,878.65$ & 11.48 & 2.01 & 12.05 \\
\hline 34 & 8 & 4 & 32 & 8 & 144 & 11.99 & 0.18 & 0.92 & $17,126,143.68$ & 0.36 & 0.92 & $34,504.87$ & 11.03 & 1.59 & 12.70 \\
\hline 35 & 8 & 6 & 48 & 12 & 96 & 11.02 & 0.22 & 0.84 & $32,536,358.75$ & 0.44 & 0.84 & $51,757.30$ & 9.76 & 1.73 & 20.82 \\
\hline 36 & 8 & 8 & 64 & 16 & 72 & 10.70 & 0.22 & 0.73 & $54,567,511.67$ & 0.44 & 0.73 & $69,009.74$ & 9.52 & 1.70 & 27.20 \\
\hline
\end{tabular}

$\mathrm{X}_{\mathrm{L}}$ - number of BEUs adjacent to the line; $\mathrm{X}_{\mathrm{C}}$ - number of BEUs adjacent to the column; and $\mathrm{n}$ - number of plots with $\mathrm{X}$ BEU of size (n=4,608/X).

A values ranged from 44.10 to 9.17 , and the estimated plot size values were 6.96 and $0.97 \mathrm{BEU}$, respectively (Table 3). Parameter A has a direct influence on plot size estimation, with a high degree of association between variables. Such behavior is similar to that observed in the study by OLIVEIRA et al. (2006) in potato crop.

The estimates of A, B, V1, and b in the two sowing seasons were accurate, considering that the 
Table 3 - Basic experimental unit (BEU) plans with size $\mathrm{X}=\mathrm{X}_{\mathrm{L}} \times \mathrm{X}_{\mathrm{C}}$, in BEU and $\mathrm{m}^{2}$, and respective estimates of the parameters of the functions $\mathrm{CV}(\mathrm{x})=\mathrm{A} / \mathrm{X}^{\mathrm{B}}$ and $\mathrm{VU}(\mathrm{x})=\mathrm{V} 1 / \mathrm{X}^{\mathrm{b}}$, coefficient of determination $\left(\mathrm{R}^{2}\right)$, mean of fresh matter in the plots of a BEU $(\mathrm{m})$, coefficient of variation of the optimum plot size $\left(\mathrm{CV}_{\mathrm{Xo}}\right.$, in \%), optimum plot size obtained by modified maximum curvature method (Xo, in UEB; and Xo in $\left.\mathrm{m}^{2}\right)$ for the fresh matter of sunn hemp (Crotalaria juncea L.), evaluated at 97 days after sowing (second sowing season), in uniformity trial with $4,608 \mathrm{BEU}$ of $0.5 \times 0.5 \mathrm{~m}\left(0.25 \mathrm{~m}^{2}\right)$.

\begin{tabular}{|c|c|c|c|c|c|c|c|c|c|c|c|c|c|c|c|}
\hline Plan & $\mathrm{X}_{\mathrm{L}}$ & $\mathrm{X}_{\mathrm{C}}$ & $\begin{array}{c}\mathrm{X} \\
(\mathrm{BEU})\end{array}$ & $\begin{array}{c}X \\
\left(\mathrm{~m}^{2}\right)\end{array}$ & $\mathrm{n}$ & A & B & $\mathrm{R}^{2}$ & V1 & $\mathrm{b}$ & $\mathrm{R}^{2}$ & $\mathrm{~m}$ & $\mathrm{CV}_{\mathrm{Xo}}$ & $\begin{array}{c}\text { Xo } \\
\text { (BEU) }\end{array}$ & $\begin{array}{c}\text { Xo } \\
\left(\mathrm{m}^{2}\right)\end{array}$ \\
\hline 1 & 1 & 1 & 1 & 0.25 & 4608 & 44.10 & 0.39 & 0.99 & $151,998.96$ & 0.78 & 0.99 & 884.11 & 20.74 & 6.96 & 1.74 \\
\hline 2 & 1 & 2 & 2 & 0.5 & 2304 & 33.29 & 0.36 & 0.97 & $346,507.13$ & 0.73 & 0.97 & $1,768.22$ & 17.85 & 5.55 & 2.78 \\
\hline 3 & 1 & 3 & 3 & 0.75 & 1536 & 28.55 & 0.35 & 0.96 & $573,468.66$ & 0.71 & 0.96 & $2,652.33$ & 16.30 & 4.90 & 3.67 \\
\hline 4 & 1 & 4 & 4 & 1 & 1152 & 26.46 & 0.36 & 0.95 & $875,625.54$ & 0.71 & 0.95 & $3,536.44$ & 15.31 & 4.65 & 4.65 \\
\hline 5 & 1 & 6 & 6 & 1.5 & 768 & 23.06 & 0.34 & 0.93 & $1,496,130.72$ & 0.68 & 0.93 & $5,304.66$ & 14.30 & 4.10 & 6.15 \\
\hline 6 & 1 & 8 & 8 & 2 & 576 & 21.53 & 0.35 & 0.91 & $2,318,682.05$ & 0.70 & 0.91 & $7,072.88$ & 13.33 & 3.95 & 7.90 \\
\hline 7 & 2 & 1 & 2 & 0.5 & 2304 & 32.09 & 0.36 & 0.98 & $321,974.63$ & 0.71 & 0.98 & $1,768.22$ & 17.69 & 5.35 & 2.68 \\
\hline 8 & 2 & 2 & 4 & 1 & 1152 & 23.94 & 0.32 & 0.97 & $716,750.03$ & 0.65 & 0.97 & $3,536.44$ & 15.14 & 4.12 & 4.12 \\
\hline 9 & 2 & 3 & 6 & 1.5 & 768 & 20.49 & 0.31 & 0.96 & $1,180,959.77$ & 0.61 & 0.96 & $5,304.66$ & 13.88 & 3.56 & 5.34 \\
\hline 10 & 2 & 4 & 8 & 2 & 576 & 18.70 & 0.30 & 0.95 & $1,750,165.95$ & 0.61 & 0.95 & $7,072.88$ & 13.03 & 3.30 & 6.60 \\
\hline 11 & 2 & 6 & 12 & 3 & 384 & 16.33 & 0.28 & 0.94 & $3,000,212.26$ & 0.57 & 0.94 & $10,609.32$ & 12.13 & 2.85 & 8.55 \\
\hline 12 & 2 & 8 & 16 & 4 & 288 & 14.84 & 0.28 & 0.91 & $4,406,605.15$ & 0.56 & 0.91 & $14,145.76$ & 11.37 & 2.61 & 10.44 \\
\hline 13 & 3 & 1 & 3 & 0.75 & 1536 & 27.83 & 0.34 & 0.98 & $544,847.62$ & 0.67 & 0.98 & $2,652.33$ & 16.50 & 4.71 & 3.53 \\
\hline 14 & 3 & 2 & 6 & 1.5 & 768 & 21.11 & 0.31 & 0.98 & $1,253,527.48$ & 0.61 & 0.98 & $5,304.66$ & 14.24 & 3.63 & 5.45 \\
\hline 15 & 3 & 3 & 9 & 2.25 & 512 & 18.21 & 0.29 & 0.97 & $2,099,054.36$ & 0.58 & 0.97 & $7,956.99$ & 13.11 & 3.13 & 7.04 \\
\hline 16 & 3 & 4 & 12 & 3 & 384 & 16.63 & 0.28 & 0.96 & $3,111,475.67$ & 0.56 & 0.96 & $10,609.32$ & 12.39 & 2.86 & 8.59 \\
\hline 17 & 3 & 6 & 18 & 4.5 & 256 & 14.64 & 0.26 & 0.94 & $5,424,470.09$ & 0.51 & 0.94 & $15,913.98$ & 11.62 & 2.45 & 11.02 \\
\hline 18 & 3 & 8 & 24 & 6 & 192 & 13.36 & 0.25 & 0.91 & $8,040,135.49$ & 0.50 & 0.91 & $21,218.64$ & 10.95 & 2.22 & 13.34 \\
\hline 19 & 4 & 1 & 4 & 1 & 1152 & 23.67 & 0.30 & 0.93 & $700,506.72$ & 0.60 & 0.93 & $3,536.44$ & 15.77 & 3.91 & 3.91 \\
\hline 20 & 4 & 2 & 8 & 2 & 576 & 17.47 & 0.25 & 0.92 & $1,527,237.84$ & 0.51 & 0.92 & $7,072.88$ & 13.48 & 2.79 & 5.58 \\
\hline 21 & 4 & 3 & 12 & 3 & 384 & 15.06 & 0.23 & 0.94 & $2,552,233.93$ & 0.46 & 0.94 & $10,609.32$ & 12.42 & 2.31 & 6.93 \\
\hline 22 & 4 & 4 & 16 & 4 & 288 & 13.46 & 0.21 & 0.89 & $3,627,807.26$ & 0.42 & 0.89 & $14,145.76$ & 11.65 & 1.98 & 7.92 \\
\hline 23 & 4 & 6 & 24 & 6 & 192 & 11.87 & 0.19 & 0.90 & $6,348,929.67$ & 0.38 & 0.90 & $21,218.64$ & 10.82 & 1.63 & 9.80 \\
\hline 24 & 4 & 8 & 32 & 8 & 144 & 10.47 & 0.16 & 0.89 & $8,777,026.91$ & 0.32 & 0.89 & $28,291.51$ & 10.09 & 1.26 & 10.11 \\
\hline 25 & 6 & 1 & 6 & 1.5 & 768 & 21.23 & 0.30 & 0.96 & $1,268,098.55$ & 0.60 & 0.96 & $5,304.66$ & 14.46 & 3.61 & 5.41 \\
\hline 26 & 6 & 2 & 12 & 3 & 384 & 16.14 & 0.26 & 0.95 & $2,933,900.95$ & 0.53 & 0.95 & $10,609.32$ & 12.42 & 2.70 & 8.09 \\
\hline 27 & 6 & 3 & 18 & 4.5 & 256 & 13.81 & 0.24 & 0.97 & $4,831,672.58$ & 0.47 & 0.97 & $15,913.98$ & 11.45 & 2.20 & 9.92 \\
\hline 28 & 6 & 4 & 24 & 6 & 192 & 12.71 & 0.23 & 0.93 & $7,273,479.26$ & 0.46 & 0.93 & $21,218.64$ & 10.79 & 2.03 & 12.17 \\
\hline 29 & 6 & 6 & 36 & 9 & 128 & 11.11 & 0.20 & 0.96 & $12,501,275.67$ & 0.40 & 0.96 & $31,827.95$ & 10.10 & 1.61 & 14.49 \\
\hline 30 & 6 & 8 & 48 & 12 & 96 & 10.02 & 0.18 & 0.95 & $18,074,138.46$ & 0.36 & 0.95 & $42,437.27$ & 9.47 & 1.36 & 16.37 \\
\hline 31 & 8 & 1 & 8 & 2 & 576 & 19.59 & 0.28 & 0.93 & $1,920,508.04$ & 0.56 & 0.93 & $7,072.88$ & 14.05 & 3.27 & 6.53 \\
\hline 32 & 8 & 2 & 16 & 4 & 288 & 14.78 & 0.24 & 0.90 & $4,370,570.80$ & 0.47 & 0.90 & $14,145.76$ & 12.11 & 2.32 & 9.29 \\
\hline 33 & 8 & 3 & 24 & 6 & 192 & 12.80 & 0.21 & 0.91 & $7,380,395.85$ & 0.42 & 0.91 & $21,218.64$ & 11.19 & 1.89 & 11.35 \\
\hline 34 & 8 & 4 & 32 & 8 & 144 & 11.73 & 0.20 & 0.83 & $11,021,388.03$ & 0.40 & 0.83 & $28,291.51$ & 10.56 & 1.69 & 13.55 \\
\hline 35 & 8 & 6 & 48 & 12 & 96 & 10.23 & 0.16 & 0.83 & $18,848,345.24$ & 0.32 & 0.83 & $42,437.27$ & 9.87 & 1.25 & 14.98 \\
\hline 36 & 8 & 8 & 64 & 16 & 72 & 9.17 & 0.14 & 0.77 & $26,934,403.39$ & 0.27 & 0.77 & $56,583.03$ & 9.20 & 0.97 & 15.59 \\
\hline
\end{tabular}

$\mathrm{X}_{\mathrm{L}}$ - number of BEUs adjacent to the line; $\mathrm{X}_{\mathrm{C}}$ - number of BEUs adjacent to the column; and $\mathrm{n}$ - number of plots with $\mathrm{X}$ BEU of size ( $\mathrm{n}=4,608 / \mathrm{X}$ ).

determination coefficients $\left(\mathrm{R}^{2}\right)$ for seasons 1 and 2 ranged from 0.73 to 0.99 and 0.77 and 0.99 , respectively (Tables 2 and 3). A slight decrease in $\mathrm{R}^{2}$ values was noticed with increasing BEU size.

The V1 estimates presented a linear growth pattern relative to the increase in BEU, and lower scores were obtained for season 2 when compared to season 1. Variability of V1 can be evidenced independently of the evaluated characteristic and the unit of measurement adopted. In wheat, variability in V1 estimates was reported between agricultural years, traits, and environments in the same year (LORENTZ et al., 2007).

It can be concluded that the optimum plot size for the evaluation of fresh matter of sunn hemp depends on BEU size. OLIVEIRA et al. (2005) observed the effect of BEU size $(1,2,3,4,6,8$, and 12 pits) on the optimum plot size, as estimated by the modified maximum curvature method (MEIER \& LESSMAN, 1971), concluding that BEU size influences the optimum plot size estimation without affecting the experimental precision. Size of the BEU should be as small as possible 


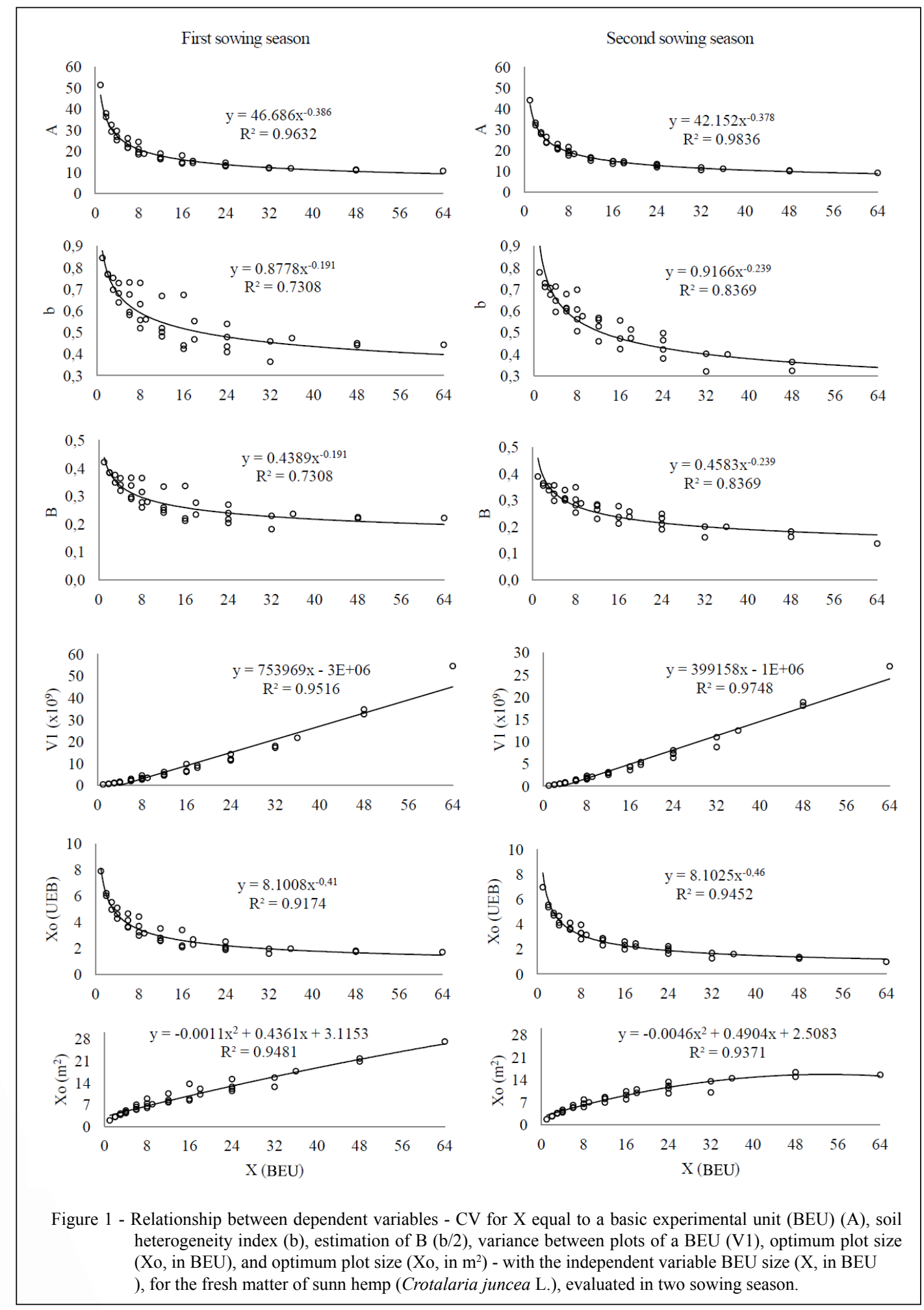

Ciência Rural, v.48, n.5, 2018. 
to avoid overestimating the optimum plot size, since the optimum plot size is influenced by the uniformity trial size (STORCK et al., 2006).

Results concordant with the present study were reported for the sunn hemp crop by FACCO et al. (2017). The authors concluded that the optimum plot size estimated using the method of maximum curvature of coefficient of variation model (PARANAÍBA et al., 2009) depends on the size of the BEU and that, with the addition of BEU size (X, BEU), there was a reduction in the optimum plot size in BEU (Xo, in BEU), with the power model pattern. Similarly, for the estimation of the Paranaíba method for white lupine (CARGNELUTTI FILHO et al., 2016b) and forage turnip (CARGNELUTTI FILHO et al., 2016a), the addition of BEU size (X, BEU) promotes a reduction in optimum plot size (Xo, in BEU), with the power model pattern.

For the production of potato tubers, OLIVEIRA et al. (2005) concluded that the relationship between the optimum plot size $\left(\mathrm{Xo}\right.$, in $^{2}$ ), as estimated by the modified maximum curvature method (MEIER \& LESSMAN, 1971), and the BEU size (X, in BEU) was expressed by the quadratic model $\left(\mathrm{Xo}=0.5287+0.3169 \mathrm{X}+0.0243 \mathrm{X}^{2}\right.$; $\mathrm{R}^{2}=0.9855$ ). The method of maximum curvature of coefficient of variation model (PARANAÍBA et al., 2009) demonstrated a positive linear relationship based on fresh matter from white lupine (CARGNELUTTI FILHO et al., 2016b), forage turnip (CARGNELUTTI FILHO et al., 2016a), and sunn hemp (FACCO et al., 2017). In this study, the relationship between $\mathrm{Xo}\left(\mathrm{m}^{2}\right)$ and $\mathrm{X}(\mathrm{BEU})$ was quadratic for both sowing seasons (Figure 1). Distinction between results might be associated with differences between crops, estimation methods, and planned BEU size.

Results obtained in this study using the method described by MEIER \& LESSMAN (1971) led to the conclusion that the estimation of optimum plot size depends on BEU size, and it was indicated that the evaluation of fresh matter in BEUs of the smallest possible size should be used to estimate optimum plot size. The size of the BEU is a determinant factor in the estimation of optimum plot size (MEIER \& LESSMAN, 1971). Therefore, when planning an experiment, it is important to consider the design of the BEU in addition to the possible limitations of the experimental area and financial costs.

\section{CONCLUSION}

Estimation of the optimum plot size, to evaluate the fresh matter of sunn hemp (Crotalaria juncea L.) by modified maximum curvature method of MEIER \& LESSMAN (1971), depends on the basic experimental unit (BEU) size. Assessing fresh matter in BEUs that are as small as possible is recommended in order to use it to estimate the optimum plot size.

\section{ACKNOWLEDGEMENTS}

We thank the Conselho Nacional de Desenvolvimento Científico e Tecnológico (CNPq - Processes 305057/2013-8, and 304652/2017-2), the Coordenação de Aperfeiçoamento Pessoal de Nível Superior (CAPES), and Fundação de Amparo a Pesquisa do Esatado Rio Grande do Sul (FAPERGS) for granting scholarships for students who assisted in data collection.

\section{DECLARATION OF CONFLICTING INTERESTS}

The authors declared no potential conflicts of interest with respect to the research, authorship, and/or publication of this article.

\section{REFERENCES}

BRUM, B. et al. Optimal plot size for experiments whit grains sorghum in two times of sowing. Ciência Rural, v.38, p.315320 , 2008. Available from: <http://dx.doi.org/10.1590/S010384782008000200003>. Accessed: sept. 17, 2017.

CARGNELUTTI FILHO, A. et al. Basic experimental unit size and optimum plot size for forage turnip. Pesquisa Agropecuária Brasileira, v.51, p.309-319, 2016a. Available from: <http://dx.doi. org/10.1590/S0100-204X2016000400003 > . Accessed: sept. 17, 2017.

CARGNELUTTI FILHO, A. et al. Basic experimental units and plot sizes in white lupine. Ciência Rural, v.46, p.610-618, $2016 \mathrm{~b}$. Available from: $<$ http://dx.doi.org/10.1590/0103-8478cr20150756>. Accessed: sept. 17, 2017.

CARGNELUTTI FILHO, A. et al. Methods for estimating the optimum experimental plot size of corn hybrids single, triple and double. Ciência Rural, v.41, p.1509-1516, 2011. Available from: <http://dx.doi. org/10.1590/S0103-84782011000900004>. Accessed: sept. 17, 2017.

COLLIER, L.S. et al. Nitrogen fertilization management for maize on legume straw crop with no tillage cultivation in Gurupi, Tocantins State. Ciência Rural, v.36, p.1100-1105, 2006. Available from: $<$ http://dx.doi.org/10.1590/S0103-84782006000400009>. Accessed: sept. 17, 2017.

FACCO, G. et al. Basic experimental unit and plot sizes with the method of maximum curvature of the coefficient of variation in sunn hemp. African Journal of Agricultural Research, v.12, p.415-423, 2017. Available from: $<$ http://dx.doi.org/10.5897/AJAR2016.11814>. Accessed: sept. 17, 2017.

GOMEZ, K.A.; GOMEZ, A.A. Statistical procedures for agricultural research. 2.ed. New York: John Wiley, 1984. 680p.

HALLAUER, A.R. Estimation of soil variability and convenient plot size from corn trials. Agronomy Journal, v.56, p.493-499, 1964. Available from: < http://dx.doi.org/10.2134/agronj1964.0002196200 $5600050015 \mathrm{x}>$. Accessed: sept. 17, 2017.

HELDWEIN, A.B. et al. O clima de Santa Maria. Ciência \& Ambiente, v.38, p.43-58, 2009. 
LEAL, M.A.A. et al. Performance of crotalaria cultivated at different sowing and cutting dates. Revista Ceres, v.59, p.386-391, 2012. Available from: <http://dx.doi.org/10.1590/S0034-737X2012000300014>. Accessed: sept. 17, 2017.

LIN, C.S.; BINNS, M.R. Relative efficiency of two randomized block designs having different plot size and numbers of replications and of plots per block. Agronomy Journal, v.78, p.531-534, 1986. Available from: $<$ http://dx.doi.org/10.2134/agronj1986.0002196200 7800030029x>. Accessed: sept. 17, 2017.

LORENTZ, L.H. et al. Plot size and experimental precision in wheat trials in no-tillage system. Científica, v.35, p.129-135, 2007. Available from: <http://cientifica.org.br/index.php/cientifica/article/view/191>. Accessed: sept. 17, 2017.

MEIER, V.D.; LESSMAN, K.J. Estimation of optimum field plot shape and size for testing yield in Crambe abyssinica Hochst. Crop Science, v.11, p.648-650, 1971. Available from: $<$ http://dx.doi.org/10.2135/crops ci1971.0011183X001100050013x>. Accessed: sept. 17, 2017.

OLIVEIRA, G.M.V. et al. Size and shape of experimental plots for Eremanthus erythropappus. Revista Cerne, v.17, p.327-338, 2011. Available from: <http://dx.doi.org/10.1590/S0104-77602011000300006>. Accessed: sept. 17, 2017.

OLIVEIRA, S.J.R. et al. Heterogeneity index, variation coefficient and optimal potato plot size. Ciência Rural, v.36, p.1710 1716, 2006. Available from: <http://dx.doi.org/10.1590/S010384782006000600007>. Accessed: sept. 17, 2017.

OLIVEIRA, S.J.R. et al. Plot size and experimental unit relationship in exploratory experiments. Scientia Agricola, v.62, p.585589, 2005. Available from: <http://dx.doi.org/10.1590/S010390162005000600012>. Accessed: sept. 17, 2017.
PARANAÍBA, P.F. et al. Optimum experimental plot size: Proposition of estimation methods. Revista Brasileira de Biometria, v.27, p.255-268, 2009. Available from: <http://jaguar.fcav.unesp.br/RME/ fasciculos/v27/v27_n2/Patricia.pdf $>$. Accessed: sept. 17, 2017.

RAMALHO, M.A.P. et al. Experimentação em genética e melhoramento de plantas. Lavras: UFLA, 2012. 305p.

SANTOS, H.G. et al. Sistema brasileiro de classificação de solos. 3.ed. Rio de Janeiro: Embrapa Solos, 2013. 353p.

SMITH,H.F.An empirical law describing heterogeneity in the yields of agricultural crops. The Journal Agricultural Science, v.28, p.1-23, 1938. Avaliable from: $<$ https://doi.org/10.1017/S0021859600050516>.Accessed: sept. 17, 2017.

SOUZA, R.P. et al. Optimum plot size for evaluation of grain yield of sunflower. Revista Brasileira de Engenharia Agrícola e Ambiental, v.19, p.21-26, 2015. Available from: <http://dx.doi.org/10.1590/18071929/agriambi.v19n1p21-26>. Accessed: sept. 17, 2017.

STEEL, R.G.D. et al. Principles and procedures of statistics: a biometrical approach. 3.ed. New York: McGraw-Hill, 1997. 666p.

STORCK, L. et al. Experimentação vegetal. 3. ed. Santa Maria: UFSM, 2016. 198p.

STORCK, L. et al. Potato trial dimensions and optimum plot size estimations. Pesquisa Agropecuária Brasileira, v.41, p.903-909, 2006. Available from: $<$ http://dx.doi.org/10.1590/S0100-204X2006000600002>. Accessed: sept. 17, 2017.

TEODORO, R.B. et al. Agronomic aspects of leguminous to green fertilization in the Cerrado of the High Jequitinhonha Valley. Revista Brasileira de Ciência do Solo, v.35, p.635-640, 2011. Avaliable from: $<$ http://dx. doi.org/10.1590/S0100-06832011000200032>. Accessed: sept. 17, 2017. 